\title{
Synthesis and biodistribution of immunoconjugates of a human IgM and polymeric drug carriers
}

\author{
C.J.T. Hoes ${ }^{1}$, J. Grootoonk ${ }^{1}$, J. Feijen ${ }^{1}$, P.J. Boon ${ }^{3}$, F. Kaspersen ${ }^{3}$, P. Loeffen ${ }^{2}$, I. \\ Schlachter ${ }^{3}$, M. Winters ${ }^{2}$ and E.S. Bos ${ }^{2}$ \\ 'Department of Chemical Technology, University of Twente, Enschede, Netherlands; ${ }^{2}$ Biochemical and Pharmacological \\ Research and Development; ${ }^{3}$ Medicinal Chemistry Department, Akzo Pharma, Organon International, Oss, Netherlands
}

(Received 24 February 1991; revised version accepted 8 July 1991)

The synthesis and purification of radiolabelled immunoconjugates, composed of a human IgM monoclonal antibody directed against an intracellular tumour-associated antigen and either poly ( $\alpha$-L-glutamic acid) (PGA) or poly [N5-(2-hydroxyethyl)-L-glutamine] (PHEG) is described. Coupling of polymers to the antibody was performed through disulfide bond formation involving a single thiol group at the C-terminus of the polymer chain and 2-pyridyldisulfide groups introduced onto the antibody. The antibody was iodinated with ${ }^{131} \mathrm{I}$ before conjugation. The polymers contained tyrosinamide in a low degree of substitution and were radiolabelled with ${ }^{125} \mathrm{I}$. ${ }^{125} \mathrm{I}$-labelled PGA and PHEG were found to be stable for at least 3 days in murine and human plasma. The biodistribution in mice of the doubly labelled immunoconjugates was studied and was compared with the pharmacokinetics of the individual components.

PHEG showed a relatively slow blood clearance, the half-life being approximately $10 \mathrm{~h}$ with low uptake in liver, kidneys and spleen. PGA was rapidly cleared from the circulation and was significantly taken up in liver, kidneys and spleen. The biodistribution of both immunoconjugates was indistinguishable from that of the IgM proper, with plasma half-lives of approximately $6 \mathrm{~h}$, indicating that the pharmacokinetic properties of the immunoconjugates are largely determined by the antibody part.

Key words: NCA polymerization; Biodegradable polymer; Poly [N $\mathrm{N}^{5}$-(2-hydroxyethyl)-L-glutamine ]; Poly ( $\alpha$-L-glutamic acid)

\section{Introduction}

The targeting of drugs, radioisotopes and toxins with the aid of monoclonal antibodies (MoAbs) directed against tumour-associated antigens is an intensively studied strategy in the treatment of cancer [1-3]. The vast majority of

Correspondence to: C.J.T. Hoes, Dept. of Chemical Technology, University of Twente, P.O. Box 217, 7500 AE Enschede, Netherlands. antibodies employed in clinical investigations are MoAbs of murine origin. Most studies in which repetitive administration of immunoconjugates of these MoAbs was applied were hampered by the development of a human anti-mouse antibody (HAMA) response [1]. Recently, large quantities of human MoAbs have become available through immunisation of cancer patients with autologous tumour cells (active specific immunotherapy, ASI) and subsequent immortalisation of their peripheral blood lymphocytes 
$[4,5]$. They can be administered to humans in gram amounts without evoking an immune response or other undesirable side effects [4,5]. A human IgM resulting from this ASI programme designated as 16.88 is being studied extensively as a targeting vehicle in radio- and chemo-immunotherapy $[4,5]$. It reacts with an intracellular tumour-associated antigen with an apparent molecular mass of $10^{3} \mathrm{kDa}$ on high performance size-exclusion chromatography (HP-SEC) and around $40 \mathrm{kDa}$ on polyacrylamide gel electrophoresis in the presence of sodium dodecylsulphonate (SDS-PAGE) [6]. MoAbs to intracellular antigens like IgM 16.88 home to necrotic areas in the tumour, which results in excellent images with $\gamma$-emitting isotopes [4].

From a theoretical point of view large amounts of chemo-immunoconjugates with a molar drug/ antibody ratio of at least 50 are needed for an effective tumour regression in case ADR is used as the cytostatic drug of choice [1]. Since antibodies of the IgM type are extremely susceptible to chemical substitution, the use of intermediate drug carriers is a prerequisite in order to achieve the appropriate drug load of the immunoconjugate without affecting solubility and immunoreactivity of the targeting vehicle $[1,7]$. In the literature various macromolecular compounds have been investigated for application as intermediate drug carrier, viz. natural proteins like serum albumin, polysaccharides and synthetic polymers like poly ( $\alpha$-L-glutamic acid), PGA $[3,7]$. PGA is biodegradable, non-immunogenic and non-toxic $[8,9]$ and it allows the binding of drugs via enzymatically or hydrolytically labile bonds [3,10-14]. Until now, no data on the biodistribution of PGA and immunoconjugates of this polymer were available. The pharmacokinetic properties of PGA may be completely determined by its polyanionic character, which may result in a preferential uptake by RES organs as was observed for the polycarboxylic acid prepared from the copolymer of divinylether and maleic anhydride (pyran copolymer) [15]. If the pharmacokinetic behaviour of the PGA molecule has a major impact on the biodistribution of its immunoconjugate, it will make PGA less suit- able as intermediate drug carrier. In that case, the uncharged derivative poly[ $\mathrm{N}^{5}-(2$-hydroxyethyl)-L-glutamine ], PHEG [14,16,17], may be a better alternative.

In this paper the preparation and fractionation of PGA and PHEG and immunoconjugates of these polymers with the human MoAb 16.88 are described. The biodistribution in mice of immunoconjugates consisting of ${ }^{125} \mathrm{I}$-labelled polymers and ${ }^{131}$ I-labelled antibody was investigated and was compared with the pharmacokinetics of the parent components. The implication of the results on the use of PGA and PHEG as intermediate drug carriers in passive immunotherapy will be discussed.

\section{Materials}

THF and dioxane were refluxed overnight and distilled in the presence of sodium wire and benzophenone as an indicator. This procedure was repeated until development of a dark-blue color, indicating the absence of water. DMF was distilled in vacuo and used immediately. $N$-ethylmorpholine and triethylamine were distilled from $\mathrm{KOH}$. TFA was distilled.

The following compounds were obtained from the manufacturer indicated and were used as supplied. 2-aminoethanol, Merck, F.R.G.; anisole, Merck, F.R.G.; CDI, Merck, F.R.G.; DTT, Merck, F.R.G.; EEDQ, Serva, F.R.G.; ME, Merck, F.R.G.; MSA, Merck, F.R.G.; SPDP, Pierce, U.S.A.; TPS, Pharmacia, Sweden; triphosgene, Janssen, Belgium; $\mathrm{TyrNH}_{2}$, Serva, F.R.G.

BLG was prepared as described [18]. Cystamine free base was prepared from the dihydrochloride (Janssen, Belgium) as described [19].

Buffers were prepared from analytical grade salts, filtered and deaerated with nitrogen. Buffer I, $0.10 \mathrm{M} \mathrm{NaCl}, 0.10 \mathrm{M}$ sodium phosphate, $\mathrm{pH}$ 7.5; buffer II, $0.14 \mathrm{M} \mathrm{NaCl}, 0.05 \mathrm{M}$ Tris- $\mathrm{HCl}, \mathrm{pH}$ 8.0; buffer III, $0.10 \mathrm{M}$ Tris- $\mathrm{HCl}, 1 \mathrm{mM}$ EDTA, $\mathrm{pH} 8.5$; buffer IV, $0.01 \mathrm{M}$ sodium phosphate, 1 mM EDTA, pH 7.5; buffer $\mathrm{V}, 0.10 \mathrm{M}$ sodium phosphate, 1 mM EDTA, pH 6.0; buffer VI, 0.10 
$M$ sodium phosphate, $1 \mathrm{mM}$ EDTA, $\mathrm{pH} 7.0$; buffer VII, $0.40 \mathrm{M}$ sodium phosphate, $1 \mathrm{mM}$ EDTA, pH 7.5.

\section{Methods}

\section{Analytical procedures}

${ }^{1} \mathrm{H}$ NMR spectra were recorded on a Bruker WP $80(80 \mathrm{MHz})$. TLC was performed on silica coated on plastic sheets 60 F254 (Merck, F.R.G.) using the solvent systems chloroform/methanol/acetic acid $(85 / 10 / 5 ; \mathrm{v} / \mathrm{v})$ or $n$-butanol/ acetic acid/water $(4 / 1 / 1 ; v / v)$. Spots were visualized under UV-light or by spraying with ninhydrin solution (Merck, F.R.G.) followed by heating for $5-10 \mathrm{~min}$ at $110^{\circ} \mathrm{C}$ for detection of amino groups.

The content of PDT groups in polymeric conjugates, PDT-activated proteins and TPS was calculated from the increase in absorbance at 343 $\mathrm{nm}$ due to release of 2-pyridinethione upon reduction of the compound in buffer VI with 5-15 $\mathrm{mM}$ DTT for $1-2 \mathrm{~h}$ at room temperature using a molar absorbance coefficient of $8080 \mathrm{M}^{-1} \cdot \mathrm{cm}^{-1}$ [20]. IgM concentrations were calculated from the absorbance at $280 \mathrm{~nm}$ using an absorbance value of 1.4 for a $1 \mathrm{mg} / \mathrm{ml}$ solution. For IgM containing bound PDT groups the absorbance at $280 \mathrm{~nm}$ was corrected for the contribution of the PDT group using a molar absorbance coefficient of $5100 \mathrm{M}^{-1} \cdot \mathrm{cm}^{-1}$.

\section{Characterization of polymeric carriers}

Molecular weights of PBLG $\left(M_{w}, M_{n}\right)$ were determined by HP-SEC/LALLS using DMF as the eluent at a flow rate of $1.0 \mathrm{ml} / \mathrm{min}$. The HPSEC unit, consisting of a Waters model $6000 \mathrm{~A}$ pump and a Waters U6K injector, was connected to three Waters $\mu$ Styragel $\left(10^{5}, 10^{4}, 10^{3}\right.$ $\AA$ ) columns $(7.8 \times 300 \mathrm{~mm})$ in series. The column eluate was monitored by a Chromatix KMX-6 LALLS apparatus and a Waters R 410 differential refractometer. Refractive index increments $(\mathrm{d} n / \mathrm{d} c)$ at $633 \mathrm{~nm}$ were determined using a modified Brice-Phoenix BP-2000-V dif- ferential refractometer. The $\mathrm{d} n / \mathrm{d} c$ value of PBLG in DMF was $0.1113 \mathrm{ml} / \mathrm{g}$.

The average molecular weight of PGA $\left(\mathrm{M}_{\mathrm{w}}\right)$ was determined by intrinsic viscosity measurements in $0.19 \mathrm{M} \mathrm{NaCl}, 10 \mathrm{mM}$ sodium phosphate, $\mathrm{pH} 7.3$, using an Ubbelohde capillary dilution viscometer or capillary micro-viscometer at $25^{\circ} \mathrm{C}$. The PGA molecular weight was calculated from the intrinsic viscosity $[\eta]$ and the relation $[\eta]=4.1 \times 10^{-5} \times\left[\mathrm{M}_{\mathrm{w}}\right]^{0.94}[21]$.

The amount of residual benzylester groups in PGA was determined from the UV spectra of solutions of PGA sodium salt in water using molar absorbance coefficients of $290 \mathrm{M}^{-1} \cdot \mathrm{cm}^{-1}$ at 267 nm [10].

The content of tyrosinamide in polymeric conjugates was calculated from the absorbance at $275 \mathrm{~nm}$ in $0.1 \mathrm{M}$ sodium phosphate buffer, $\mathrm{pH}$ 7.0 , using a molar absorbance coefficient of 1400 $\mathrm{M}^{-1} \mathrm{~cm}^{-1}$ and from the absorbance at $287 \mathrm{~nm}$ in the same buffer adjusted to $\mathrm{pH} 12$ with $1 \mathrm{M}$ $\mathrm{NaOH}$ using a molar absorbance coefficient of $1900 \mathrm{M}^{-1} \cdot \mathrm{cm}^{-1}$. Corrections were made for the contribution of polymer-bound PDT groups by using PDT-PGA and PGA prepared by triethylamine-initiated polymerization of BJ.G NCA [10] as controls. The values of the tyrosinamide content determined at either 275 or $287 \mathrm{~nm}$ were identical.

The content of polymer-bound PDT groups is expressed as $\mu \mathrm{mol} / \mathrm{g}$.

\section{Polyacrylamide gel electrophoresis (PAGE)}

SDS-PAGE was performed in a V16 vertical gel electrophoresis system (BRL, U.S.A.). Proteins were separated in a linear gradient gel $(\mathrm{T}=4-26 \%, \mathrm{C}=3 \%)$ with a spacer $(\mathrm{T}=3 \%$, $\mathrm{C}=3 \%$ ) using the discontinuous buffer system of Laemmli [22]. The thickness of the gel was $1.5 \mathrm{~mm}$. Electrophoresis was carried out for 13$15 \mathrm{~h}$ at $15 \mathrm{~mA}$ at ambient temperature. After electrophoresis, gels were fixed by immersion in a solution of trichloroacetic acid $(120 \mathrm{~g} / 1)$ for $90 \mathrm{~min}$ at ambient temperature and were subsequently stained for $24 \mathrm{~h}$ by immersion in a solution containing Serva Blue G-250 (1 g/1), ammonium sulfate $(60 \mathrm{~g} / 1)$ and phosphoric acid 
$(20 \mathrm{ml} / \mathrm{l})$. The gels were then soaked for $24 \mathrm{~h}$ in aqueous methanol $(250 \mathrm{ml} / 1)$ in order to remove excess dye sol particles. The protein-dye complexes were fixed in a solution of ammonium sulfate $(50 \mathrm{~g} / 1)$.

\section{Western blot of SDS-polyacrylamide gels}

Proteins were transferred from the gel onto Immobilon ${ }^{\circledR}$ membranes by electrophoresis in a Transblot cell (Biorad, USA) using $25 \mathrm{mM}$ Tris$\mathrm{HCl}, 0.192 \mathrm{M}$ glycine, $200 \mathrm{ml} / 1$ methanol, 300 $\mathrm{mg} / 1 \mathrm{SDS}$ as transfer buffer. Blotting was carried out for $2 \mathrm{~h}$ at $10 \mathrm{~V} / \mathrm{cm}$ and $0.25 \mathrm{~A}$ at ambient temperature, the membrane being placed at the anodal side of the gel. After electroblotting the individual lanes were cut out and were fractionated as indicated in Fig. 8. Counting of membrane species was carried out with a $\gamma$-counter (Packard 5530).

\section{Synthetic procedures}

\section{$B L G N C A$}

Syntheses of N-carboxyanhydrides were performed in a hood. Phosgene present in solutions to be discarded was decomposed by adding concentrated ammonia. The reaction was performed in a 11 pear-shaped flask supplied with a reflux condenser and a drying tube containing $\mathrm{CaCl}_{2}$. Triphosgene [23] (10.0 g, $38.0 \mathrm{mmol}$ ) was added to a suspension of BLG $(20.5 \mathrm{~g}, 86.4$ $\mathrm{mmol})$ in THF (200 $\mathrm{ml})$ under vigorous stirring at room temperature. The mixture was subsequently stirred for $1 \mathrm{~h}$ at $55^{\circ} \mathrm{C}$. The resulting clear lightly yellow solution was evaporated to dryness in vacuo. The yellow oil was dissolved in THF $(200 \mathrm{ml})$ and hexanes (mixed isomers; $330 \mathrm{ml}$ ) were added gradually with stirring until the onset of crystallization. The mixture was then kept in the freezer $\left(-18^{\circ} \mathrm{C}\right)$ overnight. The white crystals were isolated by filtration and were washed with hexanes, maintaining an atmosphere of nitrogen. The product was recrystallized twice from THF/hexanes $(100 \mathrm{ml} / 120 \mathrm{ml})$ in the same manner and was finally dried in a stream of nitrogen. Yield $14.0 \mathrm{~g}(62 \%)$ of BLG NCA, m.p. $90-91.5^{\circ} \mathrm{C}\left(96-97^{\circ} \mathrm{C}[22]\right)$.

\section{Bis-PGA-cystamine}

A solution of cystamine-free base $(0.123 \mathrm{~g}$, $0.79 \mathrm{mmol}$, ratio monomer/initiator $48 \mathrm{~mole} /$ mole $)$ in dioxane $(12.9 \mathrm{ml})$ was added with stirring to a solution of BLG NCA $(10.0 \mathrm{~g}, 38.0$ $\mathrm{mmol})$ in dioxane $(240 \mathrm{ml})$. After $24 \mathrm{~h}$, a sample $(0.25 \mathrm{~g})$ was taken and the amount of BLG NCA was determined by titration with sodium methoxide in methanol using thymol blue as the indicator [24] indicating 95\% conversion of the monomer. The viscous solution was poured into ethanol (4 l) with vigorous stirring. The precipitate was isolated by filtration, washed with ethanol and dried in vacuo at room temperature using $\mathrm{KOH}$ pellets as a drying agent to give $7.0 \mathrm{~g}$ ( $84 \%)$ of a mixture of PBLG and bis-PBLG-cystamine [3].

The crude polymer $(6.7 \mathrm{~g}, 30.6 \mathrm{mmol})$ was dissolved in a mixture of anisole $(9.8 \mathrm{ml})$ and TFA ( $54 \mathrm{ml}$ ) with stirring. After $1 \mathrm{~h}$ the solution was placed in an ice bath and MSA $(54 \mathrm{ml})$ was added. The mixture was stirred for $20 \mathrm{~min}$ at $0^{\circ} \mathrm{C}$ and for $25 \mathrm{~min}$ at $20^{\circ} \mathrm{C}$. The solution was poured into diisopropylether (1.2 1) with stirring. The white precipitate was isolated by filtration, washed with diisopropylether and dried by suction. The product was dissolved in water $(250$ $\mathrm{ml})$ by adding $\mathrm{NaHCO}_{3}(2.5 \mathrm{~g})$ and $\mathrm{Na}_{2} \mathrm{HPO}_{4}$ $(5 \mathrm{~g})$ until pH 7.5. The solution was filtered $(0.45 \mu \mathrm{m}$, Millipore type HA) and was dialyzed exhaustively against water. The solution was lyophilized yielding $3.68 \mathrm{~g}(79.4 \%)$ of a mixture of bis-PGA cystamine, sodium salt, and PGA, sodium salt. The ${ }^{1} \mathrm{H}$ NMR spectrum in $\mathrm{D}_{2} \mathrm{O}$ was consistent with the structure. The amount of residual benzyl groups was 0.3 mole $\%$ as determined by UV spectroscopy.

\section{$P D T-P G A$}

Nitrogen was bubbled through a solution of bisPGA-cystamine, sodium salt, $(1.80 \mathrm{~g})$ in buffer III $(105 \mathrm{ml})$ for $15 \mathrm{~min}$. DTT $(0.272 \mathrm{~g}, 1.8$ mmol) was added and the solution was stirred 
for $2 \mathrm{~h}$ at $45^{\circ} \mathrm{C}$. After cooling to room temperature the solution was acidified to $\mathrm{pH} 2$ by the addition of $6 \mathrm{~N} \mathrm{HCl}$. The suspension of the gel precipitate was centrifuged ( $3000 \mathrm{rpm}, 10 \mathrm{~min}$ ) and the clear supernatant was discarded. The gel precipitate was resuspended in $0.01 \mathrm{M} \mathrm{HCl}(3 \times 70$ $\mathrm{ml})$ and water $(3 \times 70 \mathrm{ml})$ each time followed by centrifugation. The gel precipitate was dissolved in water $(60 \mathrm{ml})$ with stirring by adding $\mathrm{Na}_{2} \mathrm{HPO}_{4}(2.1 \mathrm{~g})$ and $\mathrm{NaOH}$ to adjust the $\mathrm{pH}$ to 8.0 , maintaining an atmosphere of nitrogen. The $\mathrm{pH}$ of the solution was then adjusted to 6.0 and TPS $(80 \mathrm{ml}$ in buffer $\mathrm{V})$ was added. The $\mathrm{mix}$ ture was left to stand for 2 days at room temperature. The TPS gel was transferred to a glass filter and the gel was washed successively with buffer $\mathrm{V}(5 \times 200 \mathrm{ml})$, buffer IV $(5 \times 200 \mathrm{ml})$ and buffer III $(5 \times 200 \mathrm{ml})$. The filtrates obtained were each acidified to $\mathrm{pH} 2.0$ with $6 \mathrm{~N}$ $\mathrm{HCl}$ yielding a gel precipitate for both the buffer $\mathrm{V}$ and buffer IV washings. On acidification of the buffer III washings to $\mathrm{pH} 2$, no precipitate was formed indicating that all PGA not bound to TPS had been removed by the prior washings in buffer $\mathrm{V}$ and IV. The gel precipitate from the buffer $\mathrm{V}$ and buffer IV washings was isolated by centrifugation and was resuspended in $0.01 \mathrm{~N} \mathrm{HCl}$ $(3 \times 100 \mathrm{ml})$ and water $(2 \times 100 \mathrm{ml})$ each time followed by centrifugation. The suspension of the polymer gel in water was finally lyophilized yielding $0.45 \mathrm{~g}(30 \%)$ of PGA, $\mathrm{H}$-form.

Buffer III ( $90 \mathrm{ml})$ and 2-mercaptoethanol (16 $\mathrm{ml}$ ) were added to the TPS gel containing bound PGA and the mixture was left to stand for 4 days at room temperature. The TPS gel was transferred to a glass filter and the gel was washed with buffer III $(5 \times 200 \mathrm{ml})$. The filtrates were combined and the solution was acidified to $\mathrm{pH} 2.0$ with $6 \mathrm{~N} \mathrm{HCl}$. The polymer precipitate was collected by centrifugation and was washed several times with $0.01 \mathrm{~N} \mathrm{HCl}$. The polymer precipitate was dissolved in a mixture of buffer VII $(50 \mathrm{ml})$ and buffer VI $(50 \mathrm{ml})$. The polymer solution was added slowly to a solution prepared by mixing a solution of PDS $(570 \mathrm{mg})$ in ethanol $(50 \mathrm{ml})$ with $0.10 \mathrm{M}$ sodium phosphate, $\mathrm{pH} 7.0(100 \mathrm{ml})$ and the mixture was stirred for 2 days at room temperature. The organic solvent was removed by rotary evaporation in vacuo and the solution was filtered. The clear filtrate was dialyzed exhaustively against water at $4^{\circ} \mathrm{C}$. The solution was filtered (0.20 $\mu \mathrm{m}$, Millipore, type HA) and was lyophilized yielding $232 \mathrm{mg}$ (13\%) of PDT-PGA, sodium salt.

Derivatization of $P G A$ and PHEG with tyrosinamide

A solution of PDT-PGA, sodium salt $(240 \mathrm{mg}$, $1.59 \mathrm{mmol})$ in water $(24 \mathrm{ml})$ was added dropwise with stirring to $0.1 \mathrm{~N} \mathrm{HCl}(100 \mathrm{ml})$. The mixture was centrifuged ( $3000 \mathrm{rpm}, 10 \mathrm{~min}$ ) and the gel precipitate was resuspended in $0.01 \mathrm{~N} \mathrm{HCl}$ $(2 \times 100 \mathrm{ml})$ and water $(100 \mathrm{ml})$ each time followed by centrifugation. A suspension of the gel precipitate in water was lyophilized yielding PDT-PGA, H-form ( $164 \mathrm{mg}, 80 \%$ ).

Derivatization of PGA. To a solution of PDTPGA, H-form, (160 mg) in DMF ( $2 \mathrm{ml}$ ) were successively added a solution of $\mathrm{H}-\mathrm{TyrNH}_{2}$ $(0.025 \mathrm{mmol})$ in DMF $(0.1 \mathrm{ml})$ and EEDQ $(0.0297 \mathrm{mmol})$ in DMF $(0.0594 \mathrm{ml})$. The mixture was stirred for 2 days at room temperature. The resulting gel was dissolved in $0.25 \mathrm{M}$ sodium phosphate buffer, $\mathrm{pH} 7.3(20 \mathrm{ml})$ and filtered $(0.45 \mu \mathrm{m})$. The solution was divided in two equal parts which were added dropwise with stirring to $0.1 \mathrm{~N} \mathrm{HCl}(100 \mathrm{ml})$. The gel precipitates were washed with $0.01 \mathrm{~N} \mathrm{HCl}$ and water followed by centrifugation as described above.

One batch of the gel precipitate was dissolved in $0.25 \mathrm{M}$ sodium phosphate, $\mathrm{pH} 7.3$, and dialyzed against water for 4 days at $4^{\circ} \mathrm{C}$. The solution was filtered $(0.45 \mu \mathrm{m}$, Millipore type $\mathrm{HA})$ and was lyophilized yielding PDT-PGA-TyrNH ${ }_{2}$, sodium salt $(86.2 \mathrm{mg}, 90 \%)$.

Derivatization of PHEG. The other batch of the gel precipitate was resuspended in water $(100$ $\mathrm{ml}$ ) and lyophilized yielding PDT-PGA-TyrNH ${ }_{2}$, H-form ( $77.2 \mathrm{mg}, 94 \%)$. To a stirred solution of this polymer in DMF (1.5 ml) were successively added saccharin $(133 \mathrm{mg}, 0.73 \mathrm{mmol})$ and CDI ( $136 \mathrm{mg}, 0.84 \mathrm{mmol}$ ). After $30 \mathrm{~min} 2$-aminoe- 
thanol $(0.072 \mathrm{ml}, 1.19 \mathrm{mmol})$ was added. The mixture was stirred for $24 \mathrm{~h}$ at room temperature, mixed with $0.25 \mathrm{M}$ sodium phosphate buffer, pH 7.3 (20 ml), acidified with solid sodium dihydrogen phosphate to $\mathrm{pH} 7.3$ and stirred for $4 \mathrm{~h}$. After centrifugation of insoluble material the solution was dialyzed against $3 \% \mathrm{NaCl}(3$ days) and water ( 3 days) at $4{ }^{\circ} \mathrm{C}$. The solution was filtered $(0.45 \mu \mathrm{m}$, Millipore type HA) and lyophilized yielding PDT-PHEG-TyrNH $\mathrm{NH}_{2}$ (76.3 $\mathrm{mg}, 73 \%$ ). Amino acid analysis after acidic hydrolysis: Glu, 1.00; 2-aminoethanol, 1.08; Tyr, 0.016 ; peptide content $80 \%$.

Fractionation of $P G A$ and $P H E G$ derivatives by $S E C$. Both tyrosinamide-substituted polymers were fractionated by gel filtration on a TSK Fraktogel HW-55S column $(95 \times 2.6 \mathrm{~cm} ; 500 \mathrm{ml})$ equilibrated in $0.1 \mathrm{M} \mathrm{NaCl}, 10 \mathrm{mM}$ sodium phosphate, pH 7.0. PDT-PGA-TyrNH $\mathrm{NH}_{2}$ was dissolved in the equilibration buffer and, prior to chromatography, was dialysed against this buffer for $24 \mathrm{~h}$ with several changes of buffer in order to prevent exclusion of the polyelectrolyte from the gel due to electrostatic effects. PDT-PHEGTyrNH $\mathrm{N}_{2}$ was dissolved in the phosphate buffer and was applied directly on the column. Elution took place at a flow rate of $35 \mathrm{ml} / \mathrm{h}$ and the UV absorbance of the eluate was monitored at 206 $\mathrm{nm}$. Fractions of $6 \mathrm{ml}$ were collected and were pooled to a 'high molecular weight' (HMW) and 'low molecular weight' (LMW) polymer fraction which were dialyzed against water at $4^{\circ} \mathrm{C}$ and then lyophilized. The separation of the crude polymers into fractions of different molecular size was confirmed by HP-SEC on a Zorbax GF 450 column equilibrated in $0.20 \mathrm{M}$ sodium phosphate buffer, $\mathrm{pH} 7.0$, at a flow rate of 1.0 $\mathrm{ml} / \mathrm{min}$. The UV absorbance of the eluate was monitored at $226 \mathrm{~nm}$ or $280 \mathrm{~nm}$.

Radiolabelling of IgM 16.88 and $\mathrm{TyrNH}_{2}$-substituted polymers

Radio-iodination was carried out following the iodogen labelling procedure. Proteins and polymers were incubated with $\mathrm{Na}^{131}$ I (IgM 16.88) or $\mathrm{Na}^{125} \mathrm{I}$ (polymers) in vials coated with $500 \mu \mathrm{g}$ iodogen for $30 \mathrm{~min}$ at $0^{\circ} \mathrm{C}$. Excess non-bound reagents were removed by gel filtration on prepacked Sephadex G-25 columns (PD10, Pharmacia, Sweden) equilibrated in PBS.

\section{Plasma stability of ${ }^{125}$ I-labelled polymers}

Unfractionated ${ }^{125}$ I-labeled carriers PDT-PGA and PDT-PHEG were incubated for $1 \mathrm{~h}$ at $37^{\circ} \mathrm{C}$ and for various periods of time up to $72 \mathrm{~h}$ at $20^{\circ} \mathrm{C}$ in murine plasma. Samples were analyzed by GPC on Zorbax GF-450 as described above. Fractions of $1 \mathrm{ml}$ were collected and radioactivity was measured with a $\gamma$-counter (Packard 5530).

Preparation of doubly labelled immunoconjugates of IgM 16.88 and PGA or PHEG

A solution of ${ }^{131}$ I-labelled IgM 16.88 in buffer I was reacted with a 200 -fold excess of SPDP to yield a substitution ratio of 16 PDT groups per mole of protein according to Carlsson et al. [20]. ${ }^{125}$ I-labelled PDT-PGA LMW and PDT-PHEG LMW were dissolved in buffer I and were incubated for $1 \mathrm{~h}$ at $37^{\circ} \mathrm{C}$ in the presence of DTT ( 50 $\mathrm{mM}$ ). Excess reducing agents as well as low-molecular weight reaction products were removed by repeated gel filtration on Sephadex G-25 (PD10) columns equilibrated in buffer I. PDT-activated ${ }^{131}$ I-labelled IgM 16.88 was mixed with the thiol-containing ${ }^{125} \mathrm{I}$-labelled polymers ( 5.3 mole of polymer thiol groups per mole of protein) and the mixtures were reacted for $24 \mathrm{~h}$ at ambient temperature. Subsequently, the reaction mixtures were applied on a column of TSK Fraktogel HW-55S $(75 \times 5 \mathrm{~cm} ; 1500 \mathrm{ml})$ equilibrated in PBS. Elution took place with PBS as eluent at a flow rate of $100 \mathrm{ml} / \mathrm{h}$. The UV absorbance of the column eluate was monitored at $280 \mathrm{~nm}$. Fractions containing the immunoconjugates were pooled and the combined fractions were concentrated to a final protein concentration of around $3 \mathrm{mg} / \mathrm{ml}$ by ultrafiltration on Amicon YM 10 . The solutions were sterilized by filtration through a $0.22 \mu \mathrm{m}$ (Millex GV, Millipore, U.S.A.) membrane. 
Biodistribution of labelled IgM 16.88, polymers and immunoconjugates in mice

$150 \mu \mathrm{l}$ of solutions containing the doubly labelled immunoconjugates or single-labelled parent compounds at concentrations varying from $0.6-3 \mathrm{mg} / \mathrm{ml}$ of PBS were injected i.v into the tail vein of mice followed by injection of $50 \mu \mathrm{l}$ of PBS in order to minimize the loss of labelled compound by bleeding. Per compound, groups of nine mice were used. At 2, 6 and $24 \mathrm{~h}$ after administration, groups of 3 mice per compound were sacrificed. The following tissues were collected: kidneys, without fat and adrenals; liver with gall-bladder; spleen; femur-bone; muscle tibialis anterior; thyroid together with the surrounding cartilage. Blood was collected by aorta puncture under ether-anaesthesia. Urine was collected by bladder punction. Blood, urine and tissues except the thyroid were weighed, and radioactivity was determined with a well-type $\gamma$ counter (Packard 5530). The ${ }^{125}$ I activity was measured after the decay of the ${ }^{131} I$ activity. The activity found in blood, urine and tissues is expressed as \% of the dose administered per gram of tissue. For the thyroid the activity is expressed as $\%$ of the dose administered.

\section{Results}

\section{Preparation of PGA with terminal thiol groups}

Thiol-PGA was prepared by the method described by Kato et al. [3] in which the thiol group is introduced at the C-terminal polymer end (Fig. 1, Table 1). A solution of BLG NCA in dioxane $(4 \mathrm{wt} \%)$ was polymerized using cystamine as the initiator $(\mathrm{A} / \mathrm{I} 48 \mathrm{~mole} / \mathrm{mole})$. The polymer which was obtained in a yield of $84 \%$ is a mixture of PBLG and bis-PBLG-cystamine [3]. The average molecular weights $\left(M_{w}, M_{n}\right)$ determined by HP-SEC/LALLS using DMF as the eluent were 84,600 $\left(M_{w}\right)$ and 39,200 $\left(M_{n}\right)$ from which degrees of polymerization of $386\left(\mathrm{DP}_{\mathrm{w}}\right)$ and $179\left(D_{n}\right)$, respectively, are calculated. The benzyl side chains of the polymer mixture were cleaved with methanesulfonic acid/trifluoroac-

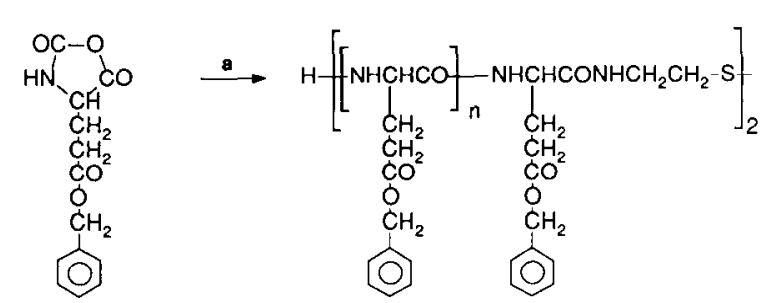

BLG NCA

bis-PBLG-cystamide

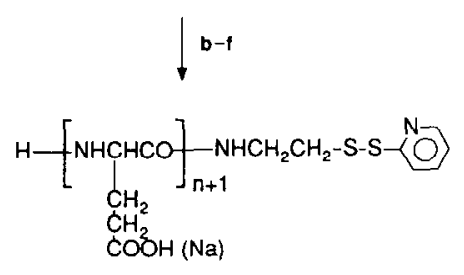

PDT-PGA

a, cystamine; b, MSA; c, DTT; d, TPS; e, ME; 1 , POS

Fig. 1. Preparation of PDT-PGA by polymerization of BLG NCA using cystamine as the initiator followed by cleavage of benzylester groups and fractionation with TPS.

etic acid in the presence of anisole to scavenge benzyl cations. The mixture of PGA and bisPGA-cystamine thus obtained was isolated in a yield of $79 \%$ relative to the benzyl-protected polymer. The polyacid was treated with DTT to reduce polymer-bound disulfide groups and thiolPGA was isolated using covalent chromatography on TPS. Thiol-PGA was converted to the PDT-derivative by treatment with PBS. PDTPGA was obtained in a yield of $13 \%$ (batch 1) or $17 \%$ (batch 2 ) relative to crude PGA (Table 1 ). These yields are lower than the yield of $31 \%$ found previously [3]. Analysis of the content of PDT groups showed values of $21.2 \mu \mathrm{mol} / \mathrm{g}$ (batch 1) and $23.4 \mu \mathrm{mol} / \mathrm{g}$ (batch 2) from which $M_{n}$ values of $40300\left(D_{n} 312\right)$ (batch 1) and $36300\left(\mathrm{DP}_{\mathrm{n}} 283\right)$ (batch 2) were calculated.

PGA not bound by TPS was isolated in yields of 30\% (batch 1) and 51\% (batch 2). The PDT content of the polymer batches was found to be $6.7-6.8 \mu \mathrm{mol} / \mathrm{g}$. The presence of PDT groups in this PGA fraction indicates that in the disulfide exchange between thiol-PGA and Sepharose- 
TABLE 1

Preparation of PDT-PGA after polymerization of BLG NCA in dioxane ( $4 \mathrm{wt} \%$ ) by cystamine (monomer/initiator ratio 48 mole/mole)

\begin{tabular}{|c|c|c|c|c|c|c|c|}
\hline Polymer & $\begin{array}{l}\text { Yield } \\
(\%)\end{array}$ & $\begin{array}{l}\text { PDT content } \\
(\mu \mathrm{mol} / \mathrm{g})\end{array}$ & $10^{4} \times M_{w}$ & $\mathrm{DP}_{\mathrm{w}}$ & $10^{4} \times M_{n}$ & $\mathrm{DP}_{\mathrm{n}}$ & $\mathrm{M}_{\mathrm{w}} / \mathrm{M}_{\mathrm{n}}$ \\
\hline PBLG + bis-PBLG-cystamine & $84^{2}$ & & $8.46^{5}$ & $386^{5}$ & $3.92^{5}$ & $179^{5}$ & 2.16 \\
\hline PGA + bis-PGA-cystamine ${ }^{1}$ & $79^{3}$ & & & & & & \\
\hline PGA not bound batch ${ }^{1}$ & $30^{4}$ & 6.7 & & & & & \\
\hline PGA not bound batch ${ }^{2}$ & $51^{4}$ & 6.8 & $4.55^{6}$ & $352^{6}$ & & & \\
\hline PDT-PGA batch ${ }^{1}$ & $13^{4}$ & 21.2 & & & $4.03^{7}$ & $312^{7}$ & \\
\hline PDT-PGA batch ${ }^{2}$ & $17^{4}$ & 23.4 & & & $3.63^{7}$ & $283^{7}$ & \\
\hline
\end{tabular}

${ }^{1}$ Amount of residual benzyl groups 0.3 mole $\% ;{ }^{2}$ Relative to BLG NCA; ${ }^{3}$ Relative to the total amount of PBI G and his-PBLGcystamine; ${ }^{4}$ After fractionation on TPS; relative to the total amount of PGA and bis-PGA-cystamine; ${ }^{5} B y$ HP-SEC/LALLS in DMF; ${ }^{6}$ By viscosimetry; ${ }^{7}$ Apparent value calculated from PDT content.

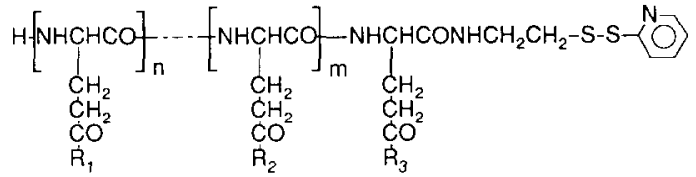

$\mathrm{TyrNH}_{2}$

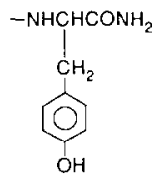

$\mathbf{n}_{1}$

$\begin{array}{llll}\text { PDT-PGA } & \mathrm{OH}(\mathrm{Na}) & \mathrm{OH}(\mathrm{Na}) & \mathrm{OH}(\mathrm{Na}) \\ \text { PDT-PGA-TyrNH } & \mathrm{OH}(\mathrm{Na}) & \mathrm{TyrNH}_{2} & \mathrm{R}_{1} \text { or } \mathrm{R}_{2} \\ \text { PDT-PHEG-TyrNH } & -\mathrm{NHCH}_{2} \mathrm{CH}_{2} \mathrm{OH} & \mathrm{TyrNH}_{2} & \mathrm{R}_{1} \text { or } \mathrm{R}_{2}\end{array}$

Fig. 2. Structure of PDT-PGA and of conjugates of PDT-PGA or PDT-PHEG and tyrosinamide.

bound 2-pyridyldithio groups the 2-pyridyl moiety is transferred to PGA besides the normally expected formation of disulfide-linked PGA-Sepharose.

\section{Preparation and fractionation of $\mathrm{TyrNH}_{2}$-substi- tuted polymers}

In order to enable labelling of the polymers with radioactive iodine, $P G A$ and $P H E G$ were substituted to a low degree with $\mathrm{TyrNH}_{2}$ (Fig. 2,
TABLE 2

Analytical data of conjugates of PGA or PHEG and $\mathrm{TyrNH}_{2}$

\begin{tabular}{|c|c|c|}
\hline Conjugate & $\begin{array}{l}\text { Tyr content } \\
\text { (mole } \%)\end{array}$ & $\begin{array}{l}\text { PDT content } \\
(\mu \mathrm{mol} / \mathrm{g})\end{array}$ \\
\hline PDT-PGA-TyrNH ${ }_{2}$ crude & $1.7^{1}$ & 26.4 \\
\hline PDT-PGA-TyrNH ${ }_{2}$ LMW & - & 23.2 \\
\hline PDT-PHEG-TyrNH ${ }_{2}$ crude & $1.3^{1}, 1.6^{2}$ & 22.2 \\
\hline PDT-PHEG-TyrNH ${ }_{2}$ LMW & $1.6^{2}$ & 15.9 \\
\hline
\end{tabular}

'From UV absorbance at $275 \mathrm{~nm}$ at pH 7 and at $288 \mathrm{~nm}$ at pH $12 ;{ }^{2}$ From amino acid analysis after acidic hydrolysis.

Table 2). $\mathrm{TyrNH}_{2}$ was linked via the amino group with a part of the carboxyl groups of PDTPGA in DMF using EEDQ as the coupling agent similar to the procedure developed by us for the coupling of $\Lambda D R$ and PGA [10]. Part of this conjugate was reacted with 2-aminoethanol using saccharin/CDI activation in DMF [10] to fully convert the carboxyl side chains into 2-hydroxyethylamide groups. The $\mathrm{TyrNH}_{2}$ content of PDT-PGA was $1.7 \mathrm{~mol} \%$ and that of PDT-PHEG was around $1.5 \mathrm{~mol} \%$. This level of substitution is supposed not to affect the general physicochemical properties of the polymers. Gel filtration of the crude PDT-PGA and PDT-PHEG preparations of TSK Fraktogel HW-55S revealed a very broad molecular weight range from apparent values of $1.5 \times 10^{3}$ to $60 \mathrm{kDa}$ (Fig. 3 ). In order to facilitate later purification of immunoconjugates of IgM 16.88 from non-conjugated 


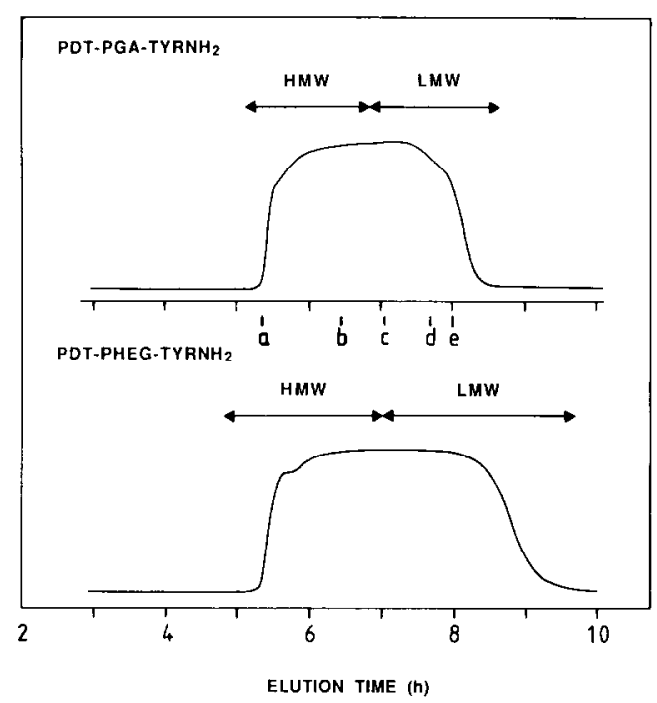

Fig. 3. Preparative SEC on Fractogel TSK HW-55S $(90 \times 2.6$ $\mathrm{cm} ; 500 \mathrm{ml}$ ) in $0.10 \mathrm{M} \mathrm{NaCl}, 10 \mathrm{mM}$ sodium phosphate, $\mathrm{pH}$ 7.0 at a flow rate of $35 \mathrm{ml} / \mathrm{h}$ at room temperature. Samples: PDT-PGA-TyrNH ${ }_{2}$ and PDT-PHEG-TyrNH ${ }_{2}$. The fractions were pooled as indicated. The elution position of reference compounds are (a), Blue Dextran 2000; (b), IgM 16.88; (c), ferritin; (d), human IgG; (e), BSA.

polymers, only those fractions of PGA and PHEG with an apparent molecular weight below $440 \mathrm{kDa}$ (ferritin), designated LMW (Fig. 3), were used for immunoconjugation. These LMW fractions contained polymers with an apparent molecular mass between 760 and $160 \mathrm{kDa}$ (PGA) or between 590 and $40 \mathrm{kDa}$ (PHEG) as was determined from the midpoints of the elution curves obtained by HP-SEC on Zorbax GF 450 (Fig. 4). The overall yield of PDT-PGA and PDT-PHEG after gel filtration on Fraktogel HW$55 \mathrm{~S}$ was excellent; for both polymers a total recovery of over $95 \%$ was found.

\section{Preparation of doubly labelled immunoconjugates of IgM 16.88 and PGA or PHEG}

The route of preparation of the immunoconjugate of IgM 16.88 and PHEG is given by way of example in Fig. 5. Prior to immunoconjugation, IgM 16.88 was labelled with ${ }^{131} \mathrm{I}$ and the LMW fractions of PDT-PGA and PDT-PHEG with ${ }^{125}$ I using the iodogen procedure. Both the antibody and polymers showed identical elution profiles in HP-SEC on Zorbax GF 450 before and after radiolabelling indicating that unwanted side effects, which may have led to crosslinking, had not taken place (data not shown). ${ }^{131}$ I-labelled IgM 16.88 was reacted with SPDP to yield a PDT substitution ratio of 16 moles of PDT per mole of antibody. This substitution level has no effect on the immunoreactivity of IgM 16.88 (E. Bos et al., unpublished results ). PDT-activated antibody was added to either of the two ${ }^{125}$ I-labelled polymers in which thiol groups had been liberated through incubation with DTT. The immunoconjugates obtained were fractionated by gel filtration on TSK Fraktogel HW-55S (Fig. 6). Because of their increased molecular weight, the immunoconjugates should elute in front of the non-conjugated IgM which is eluted between 620 and $800 \mathrm{ml}$ (Fig. 6) and non-conjugated polymers which should elute between 700 and 1000 $\mathrm{ml}$, based on the chromatographic behaviour presented above. Therefore, the UV-absorbing fractions eluting from the TSK Fraktogel HW $55 \mathrm{~S}$ column between 520 and $650 \mathrm{ml}$ were pooled as indicated (Fig. 6) as they were supposed not to contain any of the free parental compounds. HP-SEC analysis on Zorbax GF 450 of trial experiments on immunoconjugate preparations (Fig. 7) showed elution profiles of the compounds very similar to those observed with TSK Fraktogel HW 55S.

The doubly labelled immunoconjugates were subjected to SDS-PAGE and Western blotting on Immobilon ${ }^{\circledR}$ membranes (Figs. 8-11). Fractionation and counting of ${ }^{131} \mathrm{I}$ and ${ }^{125} \mathrm{I}$ activity revealed, that both labels were present in the first two fractions (Figs 9 and 10; cf. Fig. 11 ) indicating that a proper immunoconjugate had been formed. Since no ${ }^{131}$ I activity could be detected in fractions 3 and 4 of the immunoconjugates (Fig. 9), it was concluded that these preparations were devoid of free IgM. However, in spite of careful pooling after gel filtration a substantial amount of ${ }^{125}$ I activity (Fig. 10; cf. Fig. 11) was found in the lower molecular weight range showing the presence of non-conjugated PGA and PHEG. Possibly, these free polymers were attached to the antibody or immunoconjugate via 

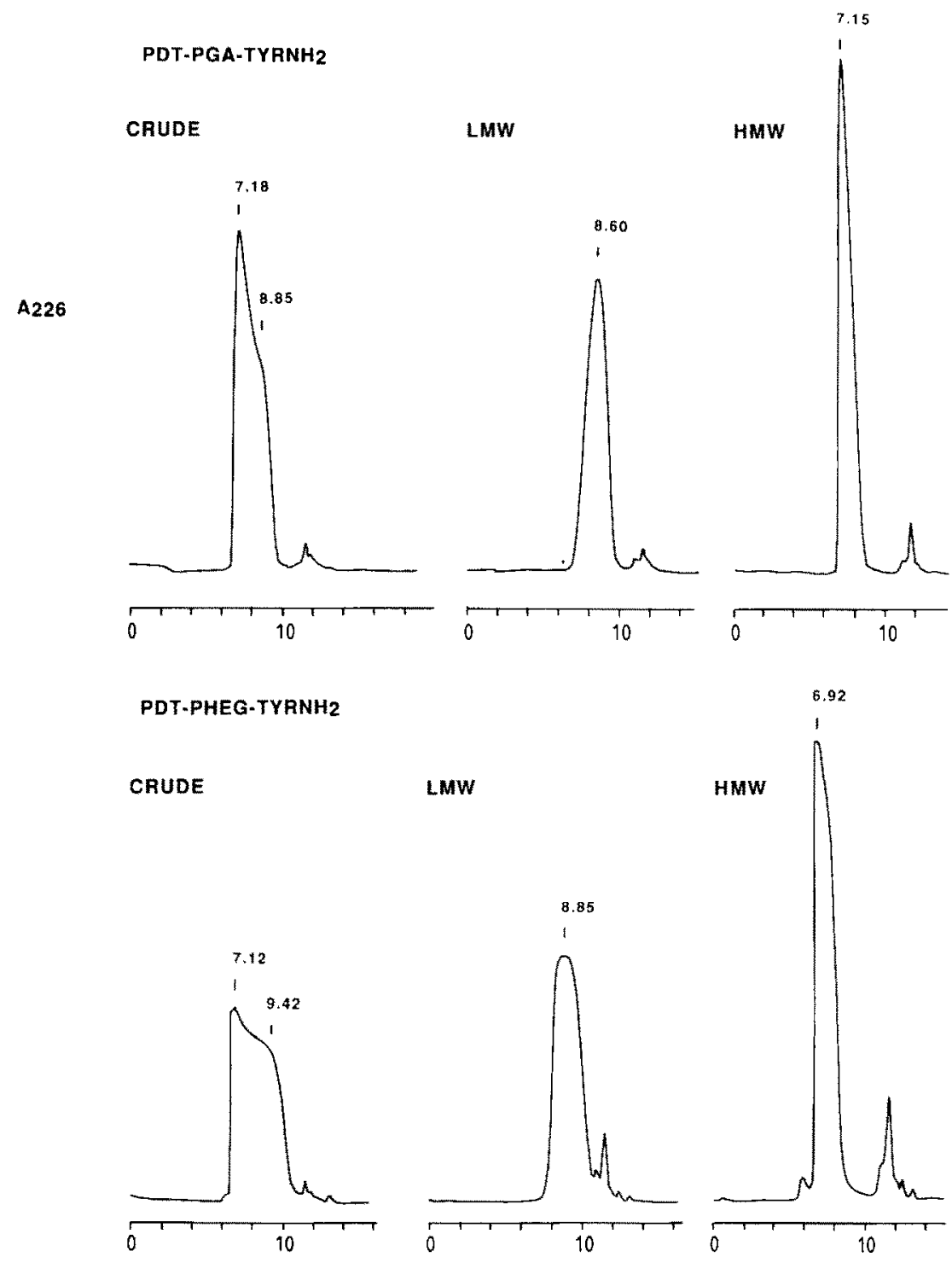

ELUTION TIME (min)

Fig. 4. HP-SEC on Zorbax GF $450(30 \times 4.6 \mathrm{~cm})$ in $0.20 \mathrm{M}$ sodium phosphate, $\mathrm{pH} 7.0$, at a flow rate of $1.0 \mathrm{ml} / \mathrm{min}$. Samples: PDT-PGA-TyrNH ${ }_{2}$ and PDT-PHEG-TyrNH ${ }_{2}$ before (crude) and after (HMW, LMW) preparative SEC (Fig. 3).

non-covalent interactions and could not be removed properly under non-denaturing conditions. Since we do not know the transfer efficiency during blotting and the binding efficiency of Immobilon membranes for the individual compounds it is difficult to estimate the amount of free polymer present in the immunoconju- gates but it may well account for up to $35 \%$ of the total ${ }^{125}$ I activity.

Plasma stability of ${ }^{125}$ I-labelled PDT-PGA and PDT-PHEG

The stability of unfractionated ${ }^{125}$ I-labelled PDT-PGA and PDT-PHEG in murine plasma 


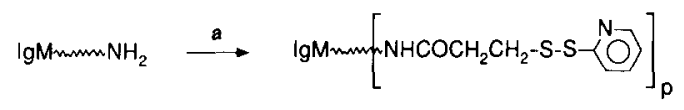

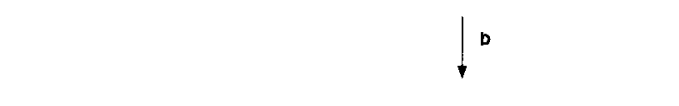

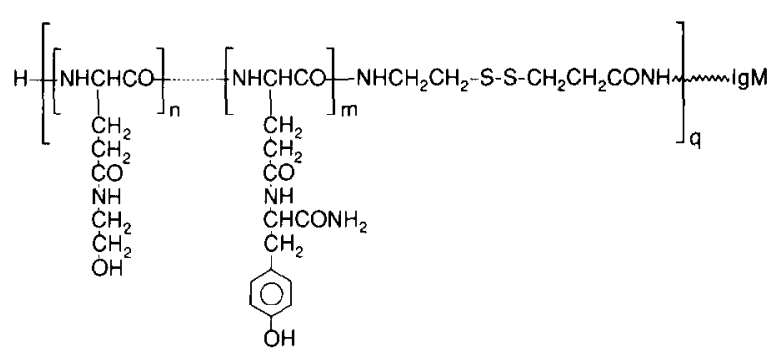

a, SPDP; b, HS-PHEG-TyrNH

Fig. 5. Preparation of immunoconjugates of IgM 16.88 and $\mathrm{TyrNH}_{2}$-containing thiol-PHEG.

was analyzed by HP-SEC on a Zorbax GF 450 column. As is shown in Fig. 12, no significant shift of radioactivity towards the low molecular weight area was observed for incubation periods up to $72 \mathrm{~h}$, indicating that both polymers were stable for that period of time.

Thus, the biodistribution studies of PGA and PHEG and the immunoconjugates will not be complicated by biodegradation of the polymers and a concomitant change in pharmacokinetic behaviour.

Biodistribution of antibody, polymers and immunoconjugates in mice

From the data presented in Fig. 13, a striking difference between the pharmacokinetic behaviour of PGA and its uncharged derivative PHEG can be observed. PGA was cleared rapidly from the circulation at a $t_{1 / 2 \beta}$ of less than $2 \mathrm{~h}$ and was taken up by liver and spleen to an appreciable extent, while its metabolisation results in a high accumulation of radiolabel in kidneys and secretion in urine on short term and an elevated uptake of iodide in the thyroid gland after $24 \mathrm{~h}$. The blood clearance of PHEG was much slower than was found for PGA, the $t_{1 / 2 \beta}$ being approximately $10 \mathrm{~h}$, which was attended by a substan-

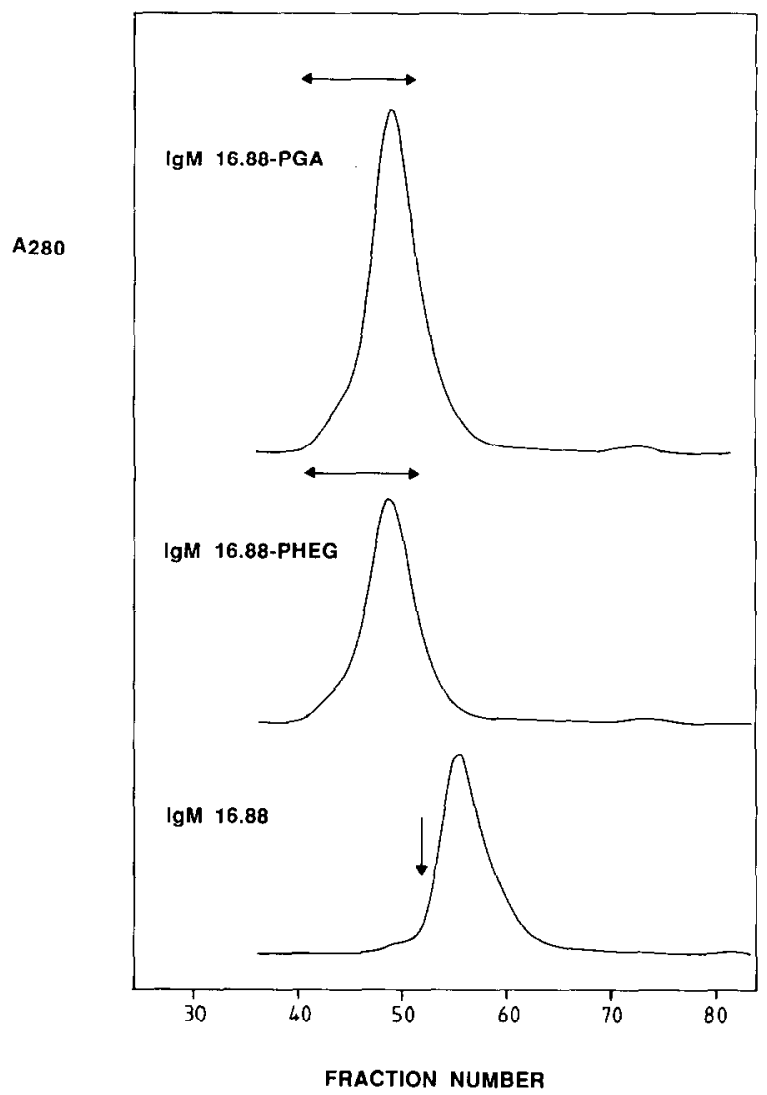

Fig. 6. Preparative SEC on Fractogel TSK HW-55S $(75 \times 5$ $\mathrm{cm} ; 1500 \mathrm{ml}$ ) in buffer $I$ at a flow rate of $100 \mathrm{ml} / \mathrm{h}$. Samples: reaction mixtures from ${ }^{131}$ I-labelled IgM 16.88 and ${ }^{125}$ I-labelled thiol-PGA LMW or thiol-PHEG LMW. The fractions (12.5 ml each) were pooled as indicated. The elution pattern of IgM 16.88 is shown for comparison.

tially lower uptake of the polymer in RES organs.

From the results it is concluded that the polyanionic character of PGA has a major impact on the biodistribution of the molecule and leads to a high uptake in liver and spleen as was predicted from the results obtained with pyran copolymer [15].

As can be seen in Fig. 14, the biodistribution of both immunoconjugates, which was derived only from the ${ }^{131} \mathrm{I}$ label on the antibody, is not affected by the polymer moiety as it is almost indistinguishable from that of the non-conjugated antibody. Antibody and immunoconjugates are cleared from the circulation at a relatively high rate, the $t_{1 / 2 \beta}$ being around $6 \mathrm{~h}$, and are accu- 


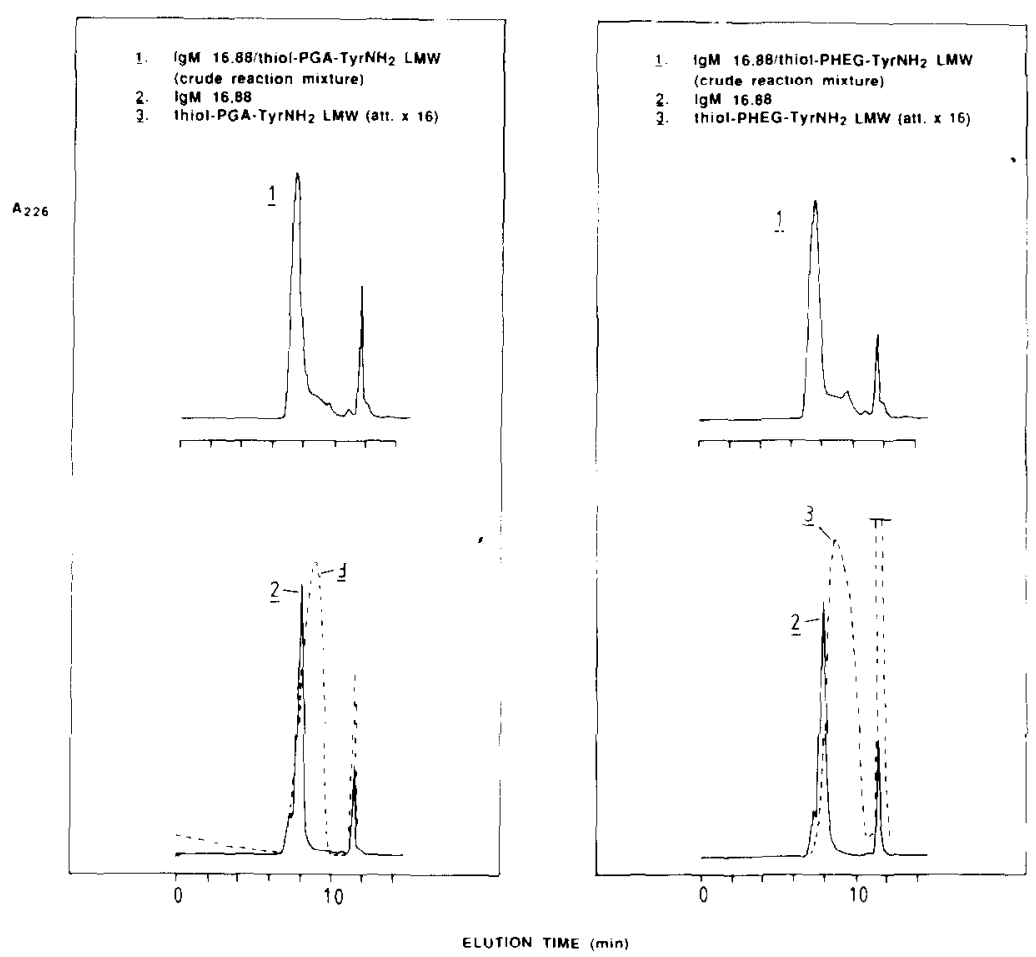

Fig. 7. HP-SEC on Zorbax GF $450(30 \times 4.6 \mathrm{~cm})$ in $0.20 \mathrm{M}$ sodium phosphate, pH 7.0, at a flow rate of $1.0 \mathrm{ml} / \mathrm{min}$. Samples: immunoconjugates of IgM 16.88 and thiol-PGA-TyrNH 2 LMW or thiol-PHEG-TyrNH ${ }_{2} \mathrm{LMW}$, IgM 16.88 and free polymers. Upper part: the arrows indicate the positions of IgM and free polymer, respectively.

mulating in an early phase in liver and spleen. Also in this case, the high uptake in thyroid after $24 \mathrm{~h}$ reflects the dehalogenation and metabolisation of the compounds injected. Since no difference in spleen uptake between free IgM and conjugates is observed, we may conclude that the immunoconjugates are devoid of large amounts of aggregates. The data on half-life in the circulation correspond quite well with previously published results where IgM 16.88 was administered to nude mice bearing tumour xenografts $[5]$.

\section{Discussion}

Monoclonal antibodies directed to tumour-associated antigens have been found to accumulate in tumours when administered in human patients $[4,5]$. This phenomenon allows in vivo diagnosis with the aid of $\gamma$-emitting isotopes at- tached to these antibodies and creates a possibility for targeted therapy with $\alpha$ - or $\beta$ emitting isotopes or cytostatic compounds $[1,2,4,5,25]$.

For optimal efficacy of these so-called radioimmunoconjugates and chemo-immunoconjugates an adequate biodistribution that allows a specific and high tumour uptake, an appropriate residence time of conjugates at the tumour site allowing the delivery of sufficient radiation dose or the release of sufficient drug, and the possibility of repeated administration are of major importance. The human MoAb IgM 16.88 shows potential for targeted therapy on the basis of its properties including the extent of tumour localization and the enhanced residence time at the tumour [4]. Due to binding of this antibody to necrotic areas in the tumour [4], we aim at the use of toxic compounds with a field effect, e.g. $\beta$ emitting isotopes or drugs bound to the antibody through acid-labile linkers where the drug is re- 


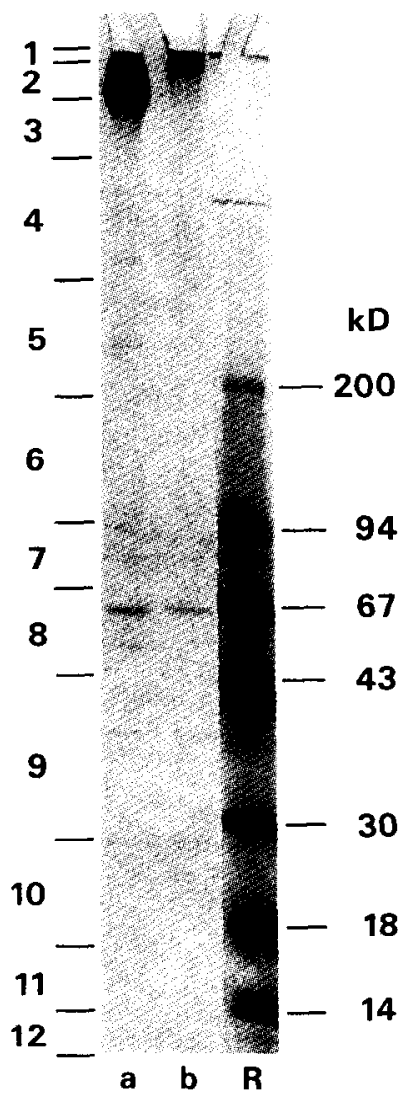

Fig. 8. SDS-PAGE of ${ }^{131}$ I-labelled IgM 16.88 (a), of doubly labelled conjugate of IgM 16.88 and PHEG (b) and of reference proteins $(R)$. The proteins were stained by Serva Blue G-250. ${ }^{131} I$ or ${ }^{125}$ I activity of fractions 1-12 (left) in Western blots was counted (Figs. 9-11).

leased at the tumour site rather than on or in the tumour cell.

In order to deliver a therapeutically effective dose of cytostatic drugs at the tumour with the set of human MoAbs available, we are obliged to use an intermediate drug carrier for which PGA and the neutral derivative PHEG were possible candidates. In order to test the applicability of these polymers in targeted drug therapy immunoconjugates of human IgM 16.88 and PGA or PHEG were synthesized and purified and were subjected to a biodistribution study.

PGA and PHEG are degradable by proteolytic enzymes [26-30]. The rate of enzyme-mediated main chain cleavage of PGA is low at $\mathrm{pH} \mathrm{7-8} \mathrm{and}$ is maximal at $\mathrm{pH} 5[25,26]$. This has been cor- related with the $\mathrm{pH}$-dependent equilibrium between the unordered conformation of PGA when anionically charged and the $\alpha$-helical conformation of PGA in the acid form with a $\mathrm{pH}$ midpoint of 5 [26,27]. PHEG is degradable by various enzymes at neutral pH [28-30]. For the use of these polymers as drug carriers in immunoconjugates, it is essential that cleavage of the main chain does not occur in the circulation and that the polymer remains intact for a reasonable time at the tumour. The data presented here indicate that the size distribution of PGA and PHEG is unaltered after incubation in murine plasma for periods up to $72 \mathrm{~h}$ and that the amount of low molecular weight material does not exceed a few percent. So, it is concluded that the polymers either free or bound to IgM 16.88 remain stable after i.v. administration in mice during the period of the biodistribution experiments.

Since the broad size distribution of the polymers hampered purification of immunoconjugates by SEC, LMW fractions of which the elution started at about the same volume as that of free IgM, were used as starting material for immunoconjugation. The observation that polymers with a molecular mass below $50 \mathrm{kDa}$ have an apparent molecular weight in the order of 320 $\mathrm{kDa}$ ( $\beta$-galactosidase) in SEC, can be explained by the fact that PGA and PHEG are randomly coiled polymers in aqueous solution [31,32]. This implies that the volume occupied by the polymer chains may be similar to that of highmolecular weight proteins which are relatively compact due to secondary and tertiary structures.

In spite of the fact that the elution profiles of the immunoconjugates suggested a complete separation from free antibody and polymer, SDSPAGE demonstrated the presence of significant amounts of free polymers indicating that a noncovalent interaction of polymer and immunoconjugate had taken place during the coupling reaction. So, the removal of residual polymer by SEC may be improved by elution under slightly denaturing conditions which do not affect the immunoreactivity of the antibody.

The presence of the free polymers, however, prevented us from analysing the in vivo stability 


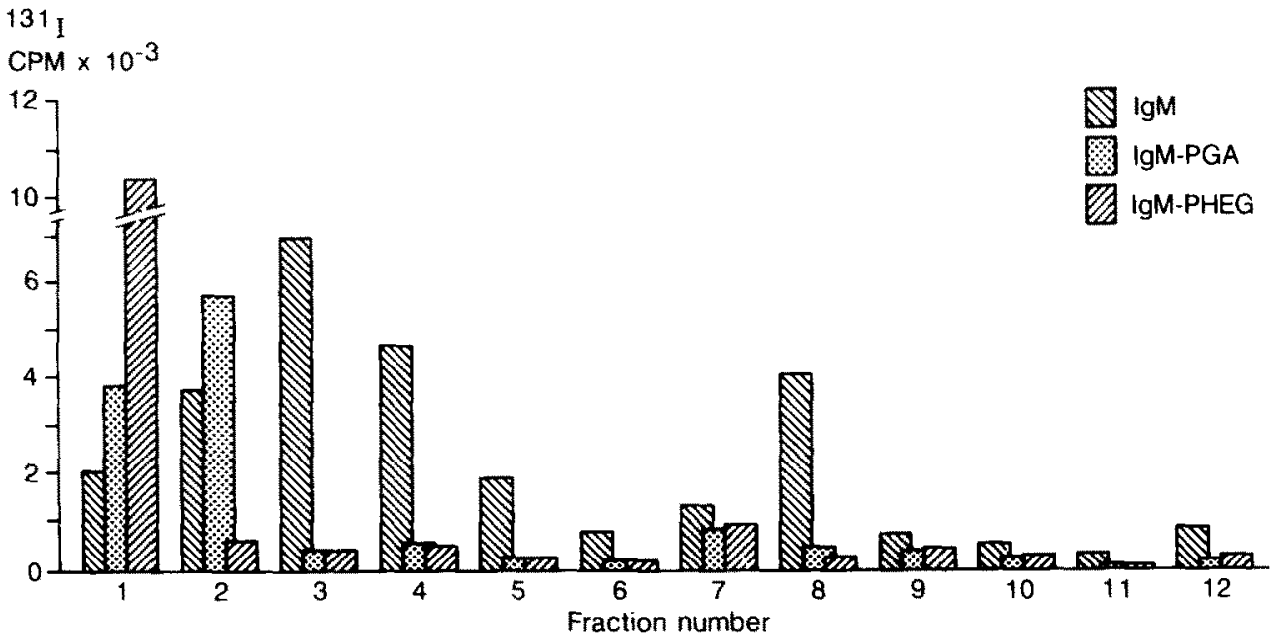

Fig. 9. ${ }^{131}$ I scans of Western blot obtained after SDS-PAGE of ${ }^{131}$ I-labelled IgM 16.88 and of doubly labelled conjugates of IgM 16.88 and PGA or PHEG.
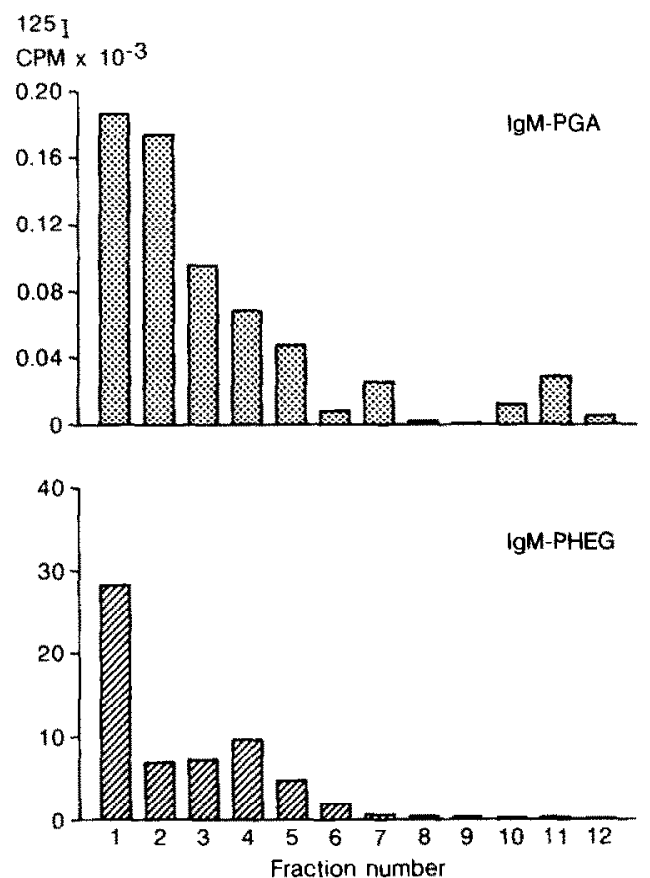

Fig. 10. ${ }^{125}$ I scans of Western blot obtained after SDS-PAGE of doubly labelled conjugates of IgM 16.88 and PGA or PHEG.

of the disulfide bonds between polymer and antibody by measuring changes in ${ }^{131} I /{ }^{125} I$ ratio with time. The instability of disulfide bridges in vivo was brought up by Thorpe et al., who ob-
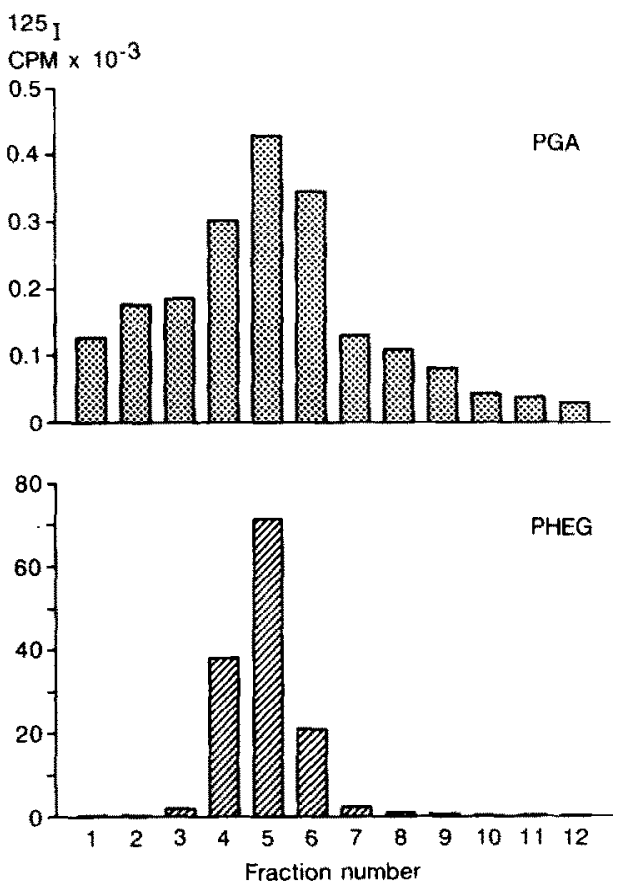

Fig. 11. ${ }^{125}$ I scans of Western blot obtained after SDS-PAGE of ${ }^{125}$ I-labelled PGA or PHEG.

served a reduction of the disulfide bond in an immunotoxin for this reason [33]. They introduced SMPT as a linker for the conjugation of antibodies and ricin A, leading to a sterically 

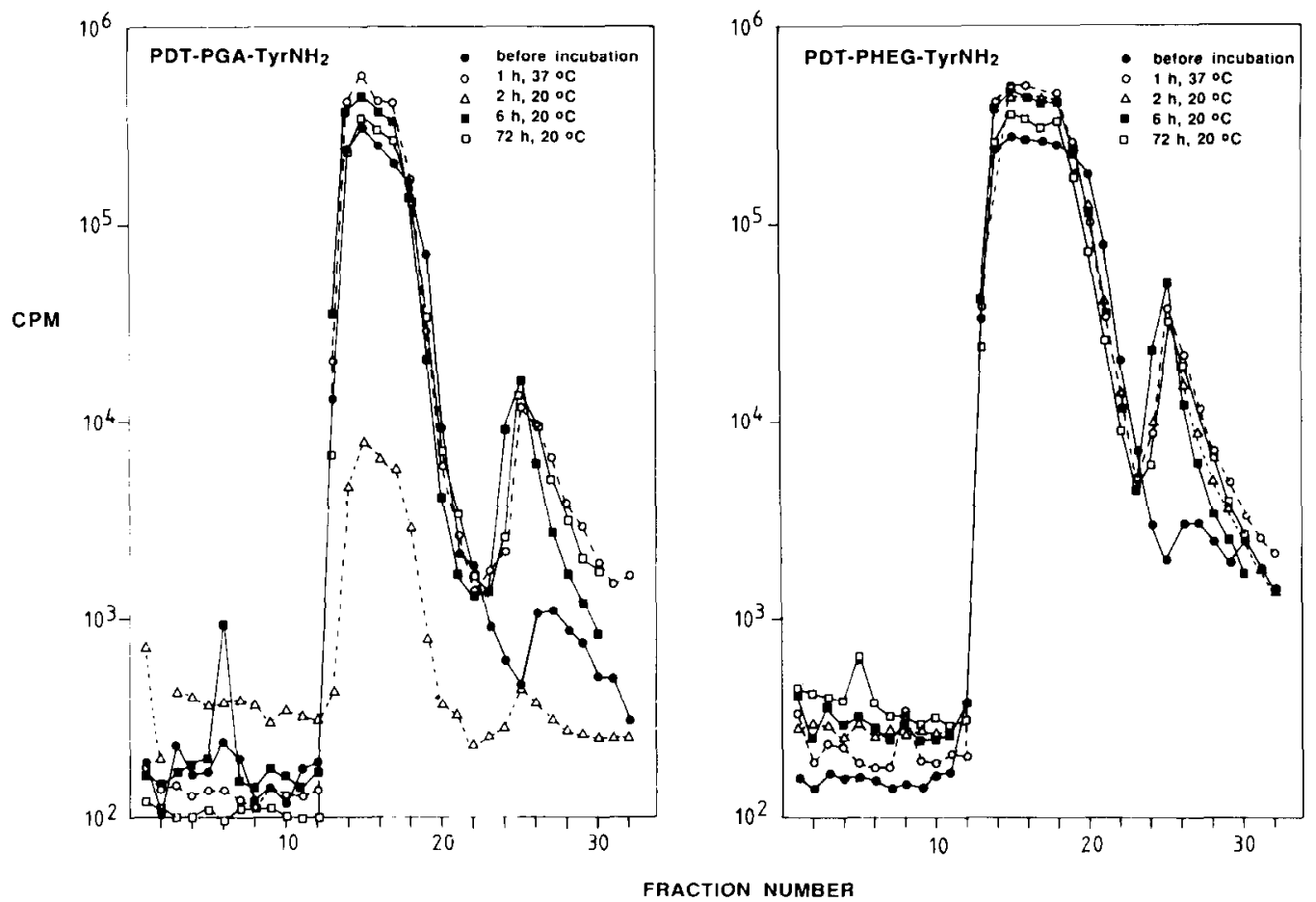

Fig. 12. HP-SEC on Zorbax GF $450(30 \times 4.6 \mathrm{~cm})$ in $0.20 \mathrm{M}$ sodium phosphate, $\mathrm{pH} 7.0$, at a flow rate of $1.0 \mathrm{ml} / \mathrm{min}$. Samples: ${ }^{125}$ I-labelled PDT-PGA and PDT-PHEG (both unfractionated) after incubation in murine plasma for the time periods indicated at $20^{\circ} \mathrm{C}$ or $37^{\circ} \mathrm{C}$.
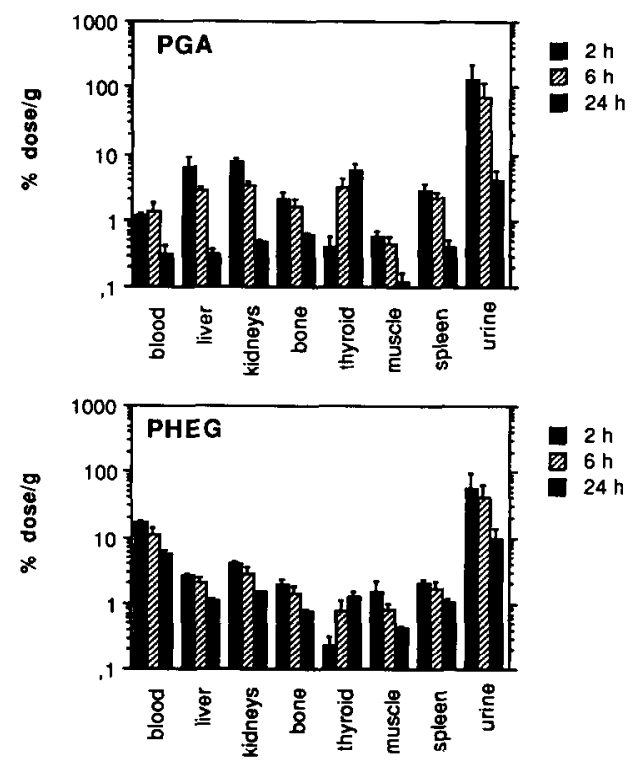

Fig. 13. Distribution of ${ }^{125} \mathrm{I}$ bound to PGA or PHEG in mice. hindered disulfide bridge between IgG and the toxin moiety. At any rate, the absence of free IgM allowed us to study biodistribution of IgM-polymer conjugates through the ${ }^{131} \mathrm{I}$ label of the antibody.

The similarity in biodistribution of immunoconjugates and free IgM as described in this paper may look surprising in view of the pharmacokinetic properties of free PGA and PHEG which were shown to be quite different. However, it has to be kept in mind that the polymers account for only $10-15 \%$ of the total mass in immunoconjugates assuming an average of three polymer chains per antibody molecule, a number that is usually found for immunoconjugates of IgM and HSA at a comparable PDT-substitution of the antibody (E. Bos et al., unpublished results ).

An important conclusion can be drawn, i.e. that the antibody molecule is the major determinant in the process of biodistribution. From 

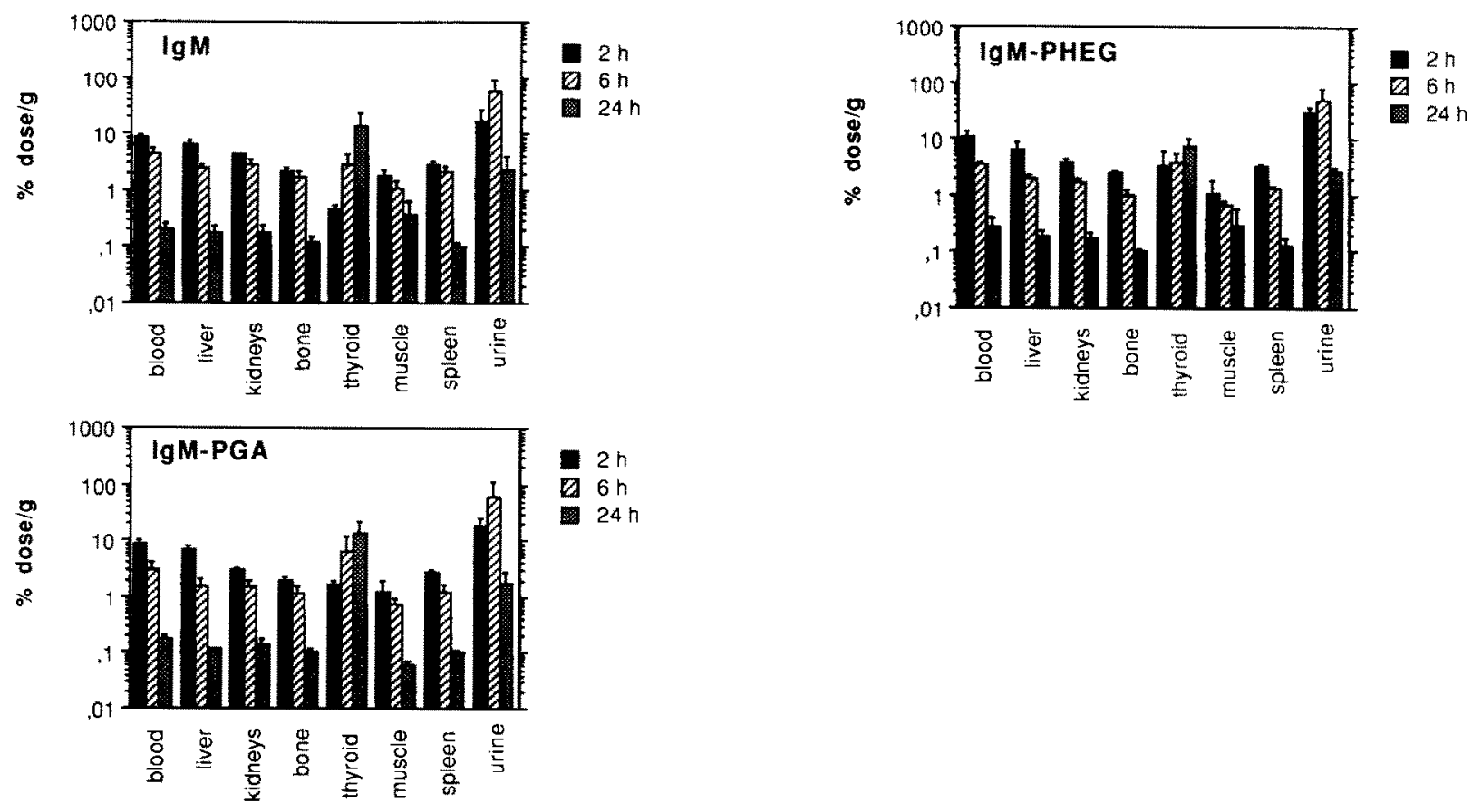

Fig. 14. Distribution of ${ }^{131} \mathrm{I}$ bound to IgM 16.88 and conjugates of IgM 16.88 and PGA or PHEG in mice.

this point of view, PGA as well as PHEG may be used as intermediate drug carriers in immunoconjugates. Since the attachment of the highly charged PGA molecule to an antibody was found to have a major impact on the physicochemical properties of the immunoconjugate in spite of its minor contribution to the mass, it might be advantageous to use PHEG as carrier instead, as the uncharged character of this derivative may be less dominant over those of the antibody, thus facilitating purification methods other than SEC, e.g. ion-exchange chromatography or hydrophobic interaction chromatography.

At present we focus on the synthesis and purification of immunoconjugates using PHEG as carrier and adriamycin as cytostatic drug which is coupled to the polymer via acid-labile bonds.

\section{Conclusions}

(1) The biodistribution of IgM 16.88 and immunoconjugates of IgM 16.88 with either PGA or PHEG are similar. (2) Both PGA and PHEG seem useful as drug carrier in immunoconjugates. (3) Removal of unbound polymers from immunoconjugates is difficult probably due to complex formation between polymers and immunoconjugates. (4) PHEG seems promising as a carrier for release of drug in the circulation due to high blood levels, slow clearance and low RES uptake.

\section{Acknowledgements}

This work has been supported by The Netherlands Organization for Scientific Research (NWO) and by the Ministry of Economic Affairs of The Netherlands.

\section{Abbreviations}

ADR, adriamycin; ASI, active specific immunotherapy; BLG, $\gamma$-benzyl-L-glutamate; BSA, bovine serum albumin; CDI, $N, N^{\prime}$-carbonyldiimidazole; DMF, $N, N^{\prime}$-dimethylformamide; DTT, dithiothreitol; EDTA, ethylene diamine tetraa- 
cetate; EEDQ, $N$-ethoxycarbonyl-2-ethoxy-1,2dihydroquinoline; HP-SEC, high-performance size exclusion chromatography; HSA, human serum albumin; LALLS, low-angle light scattering; $M_{n}$, number-average molecular weight; $M_{w}$, weight-average molecular weight; $\mathrm{ME}, 2$-mercaptoethanol; MoAb, monoclonal antibody; MSA, methanesulphonic acid; NCA, $N$-carboxyanhydride; PBLG, poly $(\gamma$-benzyl-L-glutamate); bis-PBLG-cystamine, $N, N^{\prime}$-bis [poly $(\gamma-$ benzyl-L-glutamyl) ]cystamine; PBS, phosphate-buffered saline; PDS, 2,2'-dipyridyldisulfide; PDT, 2-pyridyldithio; PDT-PGA, 2-(2pyridyldithio $)-N$-[poly $(\alpha-L-$

glutamyl) ]ethylamine; PGA, poly ( $\alpha$-L-glutamate); bisPGA-cystamine, $N, N^{\prime}$-bis [poly ( $\alpha$-Lglutamyl) ]cystamine; PHEG, poly [ $\mathrm{N}^{5}$-(2-hydroxyethyl)-L-glutamine ]; RES, reticulo-cndothelial system; SDS-PAGE, polyacrylamide gel electrophoresis in the presence of sodium dodecylsulphonate; SEC, size exclusion chromatography; SMPT, 4-succinimidyloxycarbonyl- $\alpha$ methyl- $\alpha$ (2-pyridyldithio) toluene; SPDP, $N$ succinimidyl 3-(2-pyridyldithio)propionate; TFA, trifluoroacetic acid; TLC, thin-layer chromatography; TPS, Thiopropyl Sepharose 6B; TyrNH $\mathrm{H}_{2}$, tyrosinamide.

\section{References}

1 E.S. Bos, P. Boon, F. Kaspersen and R. McCabe, Passive immunotherapy of cancer: perspectives and problems, J. Controlled Rel., 16 (1990) 101-112.

2 For a survey, see Abstracts from the Fifth International Conference on Monoclonal Antibody Immunoconjugates for Cancer, March 15-17, 1990, San Diego, USA, Antibody, Immunoconjugates and Radiopharmaceuticals, 3 (1990) 38-89.

3 Y. Kato, N. Umemoto, Y. Kayama, H. Fukushima, Y. Takeda, T. Hara and $Y$. Tsukada, A novel method of conjugation of daunomycin with antibody with a polyL-glutamic acid derivative as intermediate drug carrier. An anti- $\alpha$-fetoprotein antibody-daunomycin conjugate, J. Med. Chem., 27 (1984) 1602-1607.

4 R.G. Steis, J.A. Carrasquillo, R.P. McCabe, M.A. Bookman, J.C. Reynolds, S. Larson, J.W. Smith, J.W. Clark, V. Daily, S. Del Vecchio, N. Shuke, C. Pinsky, W.J. Urba, M. Haspel, P. Perentesis, B. Paris, D.L. Longo and M.G. Hanna Jr., An evaluation of the toxicity, immunogenicity and tumour radioimmunodetecting ability of two human monoclonal antibodies in patients with meta- static colorectal carcinoma, J. Clin. Oncol., 8 (1990) 467-490.

5 H.J. Jansma, M.A.P. Kessel, C. Silva, M. van Muijen, J.C. Roos, H. Bril, H.J. Martens, R. McCabe and E. Boven, Human IgM monoclonal antibody 16.88: pharmacokinetics and distribution in mouse and man, Br. J. Cancer, 62 (1990) Suppl. X 40-43.

6 N. Pomato, J.H. Murray, E. Bos, M.V. Haspel, R.P. McCabe and M.G. Hanna, Identification and characterization of a human colon tumor-associated antigen, CTAA 16-88, recognized by a human monoclonal antibody, in: Human tumor antigens and specific tumor therapy, pp. 127-136, Alan R. Liss Inc., 1989.

7 C.J.T. Hoes and J. Feijen, The application of drug-polymer conjugates in chemotherapy, in: Drug carrier systems, F.H.D. Roerdink and A.M. Kroon, eds, Wilcy \& Sons Ltd., Chichester, U.K., 1989, pp. 57-109.

8 P.H. Maurer, Attempts to produce antibodies to a preparation of polyglutamic acid, Proc. Soc. Exp. Hiol. Med. 96, (1957) 394-396.

9 A.D. Kenny, Evaluation of sodium poly- $\alpha$,L-glutamate as a plasma expander, Proc. Exp. Biol. Med. 100, (1959) 778-780.

10 W.A.R, van Heeswijk, C.J.T. Hoes, T. Stoffer, M.J.D. Eenink, W. Potman and J. Feijen, The synthesis and characterization of polypeptide-adriamycin conjugates and its complexes with adriamycin. Part I, J. Controlled Rel., 1 (1985) 301-315.

11 C.J.T. Hoes, W. Potman, B.G. de Grooth, J. Greve and J. Feijen, Chemical control of drug delivery, in: Innovative approaches in drug research, A.F. Harms, ed., Elsevier, Amsterdam, 1986, pp. 267-295.

12 A. Kato, Y. Takakura, M. Hashida, T. Kimura and H. Sezaki, Physico-chemical and antitumor characteristics of high molecular weight prodrugs of mitomycin C, Chem. Pharm. Bull., 30 (1982) 2951-2957.

13 C.F. Roos, S. Matsumoto, Y. Takakura, M. Hashida and H. Sezaki, Physicochemical and antitumor characteristics of some polyamino acid prodrugs of mitomycin $C$, Int. J. Pharm., 22 (1984) 75-87.

14 Y. Kato, M. Saito, H. Fukushima, Y. Takeda and T, Hara, Antitumor activity of $1-\beta$-D-arabinofuranosylcytosine conjugated with polyglutamic acid and its derivative, Cancer Res., 44 (1984) 25-30.

15 R.M. Ottenbrite, Bioactive carboxylic acid polyanions in Bioactive polymeric systems, C.G. Gebelein and C.E. Carrahar, eds, Plenum Press, New York, 1985, pp. 513529.

16 N. Lotan, A. Yaron, A. Berger and M. Sela, Conformational changes in the nonionizable watersoluble synthetic polypeptide poly-N $\mathrm{N}^{5}$-(3-hydroxypropyl)-L-glutamine, Biopolymers, 3 (1965) 625-655.

17 A. Gerola, G. Antoni, F. Benvenuti, F. Cocola and P. Neri, Poly- $\mathrm{N}^{5}$-(2-hydroxyethyl)-L-glutamine, a new plasma expander in Shock: biochemical, pharmacological and clinical aspects, A. Bertelli and N. Back, eds, Plenum Press, New York, 1970, pp. 329-338. 
18 St. Guttmann and R.A. Boissonnas, Synthèse du N-acétyl-L-séryl-L-tyrosyl-L-séryl-L-méthionyl- $\gamma$-L-glutamate de benzyle et des peptides apparantés, Helv. Chim. Acta, 41 (1958) 1852.

19 J. Barnett, J. Chem. Soc. 5 (1944).

20 J. Carlsson, H. Drevin and R. Axen, Protein thiolation and reversible protein-protein conjugation. $\mathrm{N}$-succinimidyl 3-(2-pyridyldithio)propionate, a new heterobifunctional reagent, Biochem. J., 173 (1978) 723-737.

21 M. Morcellet and C. Loucheux, Viscosity/molecularweight relationship of poly ( $\alpha$-L-glutamic acid $)$ in water and in water/dioxane mixtures, Biopolymers, 15 (1976) 1857-1862.

22 U.K. Laemmli, Cleavage of structural proteins during the assembly of the head of bacteriophage T4, Nature, 27 (1970) 680-685.

23 W.H. Daly and D. Poche, The preparation of Ncarboxyanhydrides of $\alpha$-amino acids using bis(trichloromethyl)carbonate, Tetrahedron Lett., 29 (1988) 5859-5862.

24 A. Berger, M. Sela and E. Katchalski, Titration of Ncarboxyl-alpha-amino acid anhydrides in nonaqueous solvents, Anal. Chem., 25 (1953) 1554-1555.

25 H.H. Sedlacek, G. Schulz, A. Steinstraesser, L. Kuhlmann, A. Schwarz, L. Seidel, G. Seemann, H.-P. Kraemer and $\mathrm{K}$. Bosslet, Monoclonal antibodies in tumor therapy, present stage, chances and limitations, Contributions to Oncology, Vol. 32, Karger, Basel, Switzerland, 1988.

26 W.G. Miller, Degradation of poly ( $\alpha$-L-glutamic acid). I. Degradation of high molecular weight PGA by papain, J. Am. Chem. Soc., 83 (1961) 259-265.
27 W.G. Miller, Degradation of synthetic polypeptides. II. Degradation of poly- $\alpha$,L-glutamic acid by proteolytic enzymes in $0.20 \mathrm{M}$ sodium chloride, J. Am. Chem. Soc., 86 (1964) 3913-3918.

28 T. Hayashi, Y. Tabata and A. Nakajima, Biodegradation of poly ( $\alpha$-amino acid $)$ in vitro, Polymer J., 17 (1985) 463-471.

29 Y. Yaacobi, S. Sideman and N. Lotan, A mechanistic model for the enzymatic degradation of synthetic biopolymers, Life Support Systems, 3 (1985) 313-326.

30 J. Pytela, V. Saudek, J. Drobnik and F. Rypacek, Poly ( $\mathrm{N}^{5}$-hydroxyalkylglutamines). IV. Enzymatic degradation of $\mathrm{N}^{5}$-(2-hydroxyethyl)-L-glutamine homopolymers and copolymers, J. Controlled Rel., 10 (1989) 1725.

31 R.B. Hawkins and A. Holtzer, Some macromolecular properties of poly ( $\alpha$-L-glutamic acid $)$ random coils, Macromolecules, 5 (1972) 294-301.

32 F.J. Joubert, N. Lotan and H.A. Scheraga, Nuclear mag. netic resonance studies of intramolecular motions and side-chain interactions in water-soluble polyamino acids, Biochemistry, 9 (1970) 2197-2211.

33 P.E. Thorpe, P.M. Wallace, P.P. Knowles, M.G. Relf, A.N.F. Brown, G.J. Watson, R.E. Knyba, E.J. Wawrzynczak and D.C. Blakey, New coupling agents for the synthesis of immunotoxins containing a hindered disulfide bond with improved stability in vivo, Cancer Res. 47 (1987) 5924-5931. 